\title{
A Hallgatói MUNKAVÁllalás MINT A LEMORZSOLÓDÁS EGYIK LEHETSÉGES TÉNYEZŐJE*
}

\author{
KOCSIS ZSÓFIA \\ Debreceni Egyetem, Humán Tudományok Doktori Iskola \\ Neveléstudományi Doktori Program
}

\begin{abstract}
A lemorzsolódás egyik lehetséges okaként jelenik meg a munkaerőpiac vonzása. Manapság a munkába állás időpontja nem esik egybe a diploma megszerzésének időpontjával, olykor a diploma nélkül elhelyezkedők keresete magasabb, mint a diplomával rendelkezőké (Bocsi 2013; Kun 2013). Továbbá az egyetemi tanulmányok félbeszakításához vezethet, hogy a hallgatók negatívan ítélik meg az általuk végzett szak piacképességét, s ebben az esetben még jobban érvényesül a munkaerőpiac vonzó hatása. Kvalitatív kutatásunk eredményei alapján az egyetemi tanulmányok mellett folytatott munka jelentős szerepet játszott az interjúalanyok életében, és ez hatással volt a lemorzsolódásukra. Az eredmények felhívják a figyelmet arra, hogy az egyetem melletti vagy helyetti munkavállalás vizsgálata megkerülhetetlen a felsőoktatásból történő lemorzsolódás kutatása során.
\end{abstract}

Kulcsszavakः lemorzsolódás, hallgatói munkavállalás, diákmunka, felsőoktatás

One of the possible causes of dropout is the attractiveness of the labour market. Nowadays, the date of employment does not coincide with the date when the diploma was acquired, sometimes the earnings of non-graduates were higher than those with a degree (Bocsi 2013; Kun 2013). Furthermore, it may lead to the interruption of university studies that students are negatively assessing the marketability of the profession they do, and in that case, the attractiveness of the labour market is even more stronger. In our qualitative research, the work carried out under university studies played a significant role in the interviewees' lives and this had an impact on their dropouts. The results point out that work during studies or instead studying is an inevitable test point for dropout.

Keywords: dropout, student employment, student work, higher education

Levelező szerző: Kocsis Zsófia, Debreceni Egyetem, Humán Tudományok Doktori Iskola,

Neveléstudományi Doktori Program, 4032 Debrecen, Egyetem tér 1. E-mail: zsofikocsis6@gmail.com

* A tanulmány a 123847 számú projekt a Nemzeti Kutatási Fejlesztési és Innovációs Alapból biztosított támogatással, a K17 pályázati program finanszírozásában valósult meg. 


\section{A hallgatói munkavállalás mint a lemorzsolódás egyik tényezője?}

A hallgatói munkavállalás egy kettős élü kard, egyrészt csökkentheti a hallgatók tanulmányi eredményességét, növelheti a lemorzsolódást, másrészt azonban hosszú távon pozitív hatásai lehetnek. A tanulmányok melletti foglalkoztatás pénzszerzésen túli fö előnye a munkatapasztalat gyüjtése, az önéletrajz munkatapasztalattal való gazdagítása, továbbá az is előnyként jelentkezhet, hogy a diákok egyre jobban megértik a munkaerőpiac struktúráját, müködését (Riggert et al. 2006; Markos 2014; Roshchin-Rudakov 2015; Bocsi-Fényes-Markos 2017). Emellett a munkavállalás pozitívan hat a szóbeli kommunikációs készségekre, a csapatban való munkára, javíthatja az időgazdálkodási képességet, valamint a diákok ezáltal bővíthetik kapcsolataikat, ismeretségi körüket (Sanchez-Gelabert-Figueroa-Elias 2017; Beerkens 2011).

Általánosságban elmondható, hogy nincs egy egységes definíció, amely alapján meghatározhatjuk, mit is értünk a hallgatók lemorzsolódása alatt. Lukács és Sebő (2015) szerint a hallgatói kimenetnek három lehetséges módja van: 1) végzett, 2) kilépett és 3) lemorzsolódott. A lemorzsolódott hallgatói kimenet azt jelenti, hogy a passzív félévek, a költségtérítés nem vállalása, vagy fegyelmi eljárás miatt a képzésből kizárták a hallgatót, esetleg ő maga adta le a szakot, illetve nem iratkozott be. Míg Fenyves és munkatársai (2017) szerint megkülönböztethetjük a lemorzsolódás formáit aszerint, hogy a hallgató saját maga kéri az elbocsátást, az intézmény kéri az elbocsátást (tanulmányi okok, vizsgafeltételek miatt), vagy az elbocsátásnak egészségügyi, illetve anyagi okai vannak (képzési költségek, önköltség határidőn belüli befizetése nem teljesült). Ugyanakkor a vizsgálatok középpontjában általában olyan hallgatók állnak, akik végzettség megszerzése nélkül fejezték be a felsőoktatási tanulmányaikat, s ezáltal lemorzsolódott hallgatókká váltak (Lukács-Sebö 2015; Fenyves et al. 2017).

Számos tényező fokozza a hallgatói lemorzsolódás esélyét. A kiemelt okok között szerepel a munkaerőpiac vonzása, amelynek következtében hajlandóak szakképesítés nélkül elhagyni a felsőoktatási intézményt, hogy biztosítsák, javítsák az anyagi helyzetüket (OECD 2012). Napjainkban a munka egyre nagyobb szerepet kap az egyetemisták életében. Sok időt és energiát szentelnek arra, hogy a munkavállalást beillesszék a napi rutinjukba. A Eurostudent felmérés legfrissebb, 2018-as adatai szerint a diákok valamivel több mint fele dolgozott az egyetemi tanulmányai mellett, és a hallgatók egy része munkahelyi okokra hivatkozva szakította félbe tanulmányait, vagyis náluk erősen megjelenik a munkaerőpiac vonzó hatása (Masevičiūtè-Šaukeckienè-Ozolinčiūtè 2018). Tehát a hallgatói munkavállalás értelmezhető úgy is, mint rizikófaktor, amely a lemorzsolódási kockázatot növeli azáltal, hogy távol tartja a diákokat az egyetemi kultúrába és közösségbe való beágyazódástól (Riggert et al. 2006; Darmody-Smyth 2008; Perna 2012; Pusztai 2011). Kutatások szerint magasabb a lemorzsolódási arány azoknál a hallgatóknál, akik hosszabb távon állandó munkát vállalnak (McCoy-Smyth 2004; Darmody-Smyth 2008).

Magyarországon nagymértékűnek mondható a hallgatói lemorzsolódás: az alapképzésben 36-38\%, a mesterképzésben 14-17\% (Derényi 2015). Felmerül a gyanú, hogy az intenzív hallgatói munkavállalás hozzájárul a gyengébb tanulmányi eredményhez, a követelmények teljesítésének halasztásához, sőt előbb-utóbb lemorzsolódáshoz vezet. Korábbi kutatások alátámasztották, hogy a munkaerőpiac vonzó hatása sokkal erősebb azoknál a hallgatóknál, akik nem kapnak semmilyen támogatást, ők nagyobb 
valószínűséggel és nagyobb intenzitással dolgoznak az egyetemi tanulmányaik mellett (Bocsi-Fényes-Markos 2017; Roshchin-Rudakov 2015). A Eurostudent VI. felmérés adatai szerint Magyarországon az egyetemisták 39\%-a rendszeresen vállal munkát a szemeszter ideje alatt, míg 14\%-uk időközönként dolgozik a tanulmányi időszak során. A felmérés alapján a magyar egyetemisták elsődleges motivációja a munkavállalásra a megélhetési költségek fedezése. Ezt követően a legtöbben azt nyilatkozták, hogy a fizetett munka nélkül nem engedhetnék meg maguknak, hogy egyetemisták legyenek valamint ugyanennyien a munkatapasztalat miatt is dolgoznak. A legkevesebben azért dolgoznak, mert valaki mást is kell anyagilag támogatniuk. Magyarországon a dolgozó hallgatók heti több mint 30 órát szánnak a munkavégzésre. Ez a magas óraszámú munkavállalás jelentősen befolyásolja a tanulmányokra fordított időt. Magyarországon a több mint heti 20 órát dolgozó diákok 49\%-a alacsony intenzitással tanul a munka mellett, azaz a tanulásra szánt idejük heti 0-20 óra között ingadozik, így veszélyeztetettek lehetnek a lemorzsolódás szempontjából. A tanulmányok mellett végzett munka, különösen a passzív félév ideje alatt, negatív hatást gyakorol a diploma megszerzésére. A hallgatók körülbelül 7\%-a legalább egy évre megszakította a tanulmányait. Legfőképpen a mesterszakos hallgatók szüneteltették a tanulmányaikat, és azok, akik intenzívebben dolgoznak a többi diákcsoporthoz képest. A tanulmányaikat megszakító diákok egy csoportja (25\%) jelezte, hogy munkahelyi okok miatt passziváltatták magukat (Masevičiüté-Šaukeckienè-Ozolinčiūtè 2018).

Láthatjuk, hogy az egyetem melletti munkavállalás vizsgálata megkerülhetetlen a felsőoktatásból történő lemorzsolódás kutatása során. Ezért is vállalkoztunk a felderítő jellegű kutatásunk során arra, hogy feltérképezzük, mennyire befolyásolja a munkavállalás a lemorzsolódást.

\section{A kutatás jellemzői}

Kutatásunkban lemorzsolódott vagy veszélyeztetett hallgatókkal készítettünk interjút. Veszélyeztetettnek azokat a hallgatókat tekintettük, akik esetében az átlagosnál magasabb mértékben jelennek meg passzív félévek és hallgatói előmenetelükben csúszások száma, illetve változások mentek végbe náluk a tagozat, valamint a finanszírozás tekintetében.

Hét hallgató egyetemi pályafutását mutatjuk be, ugyanis ők voltak azok az interjúalanyok, akiknek a munka többféleképpen, de folyamatosan jelen volt az életükben. Az interjúalanyok életútja és egyetemi pályafutása más és más, ugyanakkor közös vonás, hogy szociokulturális, anyagi és személyes okok mellett a rendszeres munkavégzésnek is jelentős szerepe volt abban, hogy a megkérdezett hallgatók lemorzsolódtak. Az interjúalanyok az anonimitás biztosításának érdekében egy-egy számjelzést kaptak. Az interjúalanyokról néhány fontos információt az 1. táblázatban foglaltunk össze.

\section{Az interjúelemzés eredményei}

A kutatásban részt vevő interjúalanyok nem valószínűségi mintavétellel lettek kiválasztva, ebből kifolyólag nem vonhatunk le egyértelmű konklúziót azzal kapcsolatban, hogy milyen szociokulturális háttérrel rendelkező csoportokra jellemző leginkább a tanulmányok megszakítása vagy a lemorzsolódás. Általánosságban elmondható, hogy az interjúalanyok 
1. táblázat: Az interjúalanyok jellemzése

\begin{tabular}{|c|c|}
\hline Interjúalany & Jellemzők \\
\hline Interjúalany 1 & $\begin{array}{l}\text { férfi, } 27 \text { éves, kisváros, Soproni Egyetem, Simonyi Károly Müszaki Faanyagtu- } \\
\text { dományi és Múvészeti Kar, ipari termék és formatervező mérnök szak, veszé- } \\
\text { lyeztetett: a diplomája megszerzéséhez még a szakdolgozat elkészítése, illetve a } \\
\text { sikeres záróvizsga szükséges. Jelenleg a 14. félévét tölti a felsőoktatásban. }\end{array}$ \\
\hline Interjúalany 2 & $\begin{array}{l}\text { férfi, } 24 \text { éves, község, Debreceni Egyetem Természettudományi Kar, kémia szak, } \\
\text { lemorzsolódott: fél év kihagyás után folytatta a tanulmányait }\end{array}$ \\
\hline Interjúalany 3 & $\begin{array}{l}\text { nő, } 24 \text { éves, megyeszékhely, Debreceni Egyetem Állam- és Jogtudományi Kar, jo- } \\
\text { gász, veszélyeztetett: váltás történt a képzés munkarendjében, folyamatos „csúszá- } \\
\text { sok”, lakhelyváltás }\end{array}$ \\
\hline Interjúalany 4 & $\begin{array}{l}\text { nő, } 20 \text { éves, község, Debreceni Egyetem Bölcsészettudományi Kar, pedagógiai } \\
\text { szak, veszélyeztetett: több féléves csúszásban van a munkavállalás és az általa vá- } \\
\text { lasztott minor szak nehézsége miatt }\end{array}$ \\
\hline Interjúalany 5 & $\begin{array}{l}\text { férfi, } 23 \text { éves, megyeszékhely, Debreceni Egyetem Természettudományi Kar, ve- } \\
\text { gyészmérnöki szak, veszélyeztetett: szakváltás (elsőként Informatika Karon ta- } \\
\text { nult), több passzív féléve volt }\end{array}$ \\
\hline Interjúalany 6 & $\begin{array}{l}\text { férfi, } 37 \text { éves, megyeszékhely, Nyíregyházi Főiskola, Matematika és Informatika } \\
\text { Intézet, programozó matematika szak, lemorzsolódott: állandó munkahely, idő- } \\
\text { hiány miatt, azonban pár év kihagyás után diplomát szerzett ugyanezen a szakon }\end{array}$ \\
\hline Interjúalany 7 & $\begin{array}{l}\text { férfi, } 37 \text { éves, megyeszékhely, lemorzsolódott: szakváltás, passzív félévek jellemzik, } \\
\text { végül Debreceni Egyetem andragógiai szakon szerzett diplomát több év után le- } \\
\text { velezö tagozaton }\end{array}$ \\
\hline
\end{tabular}

korának és a képzés jellegének fontos szerepe volt az egyetemi pályafutás hanyatlásában vagy a lemorzsolódás folyamatában. A tanulmányok melletti munkavégzés és a különböző egyéni, intézményi, társadalmi tényezők együttállása veszélyezteti a diplomaszerzést, azonban a jelenlegi elemzés során a legfőbb vezérfonal az egyetem melletti munkavégzés volt. Az interjúalanyok közül szinte mindenki az anyagi okok miatt vállalt munkát az egyetemi tanulmányai alatt. Néhányukat a plusz jövedelem vagy a szülőktől való függetlenedés vágya motiválta, míg néhány hallgató a költségtérítéses képzésére gyüjtött. Csupán egy olyan személy volt, aki a tapasztalatszerzés miatt vállalt munkát és szakította meg az egyetemi tanulmányait. Az interjúalanyok lemorzsolódásának folyamatát az alapján mutatjuk be, ahogyan viszonyultak a munkához.

Az első körben azokkal a hallgatókkal foglalkoztunk, akik tipikus példái a munkavállaló diákoknak. Korábbi kutatásokból (Bocsi 2013; Kocsis 2017; Masevičiūtè-ŠaukeckienèOzolinčiūtė 2018) is kiderült, hogy a legtöbb egyetem mellett dolgozó hallgató a pénzügyi nehézségek miatt keres munkát. Az első három interjúalany az anyagi kényszer miatt vállalt munkát az egyetemi évei alatt. Az anyagi kényszer a szülői támogatás hiányából vagy a tandíj befizetésének kötelezettségéböl fakadt.

„Többször dolgoztam gyárakban, üzletekben diákmunkásként, kertészetben, épitkezésen. Egy ideig volt szociális támogatás, egyszer volt tanulmányi ösztöndijam, volt egy jobb félévem..." (Interjúalany 1)

„Eleinte nem vállaltam munkát, a későbbiekben már rá voltam szorulva, és úgymond ez a mai napig tart. Eleinte az bosszantott, hogy a környezetemben szinte mindenki az enyémnél 
nagyságrendekkel nagyobb zsebpénzzel érkezett. Amellett döntöttem, hogy munkát vállalok. Volt olyan munkahely, ahová egy hónapban 2-3-szor kellett elmenni, nyilván ez nem jelentett anyagiakban nagy segitséget." (Interjúalany 2)

Meglátásunk szerint a munkavállalás nagymértékben negatív hatással volt a tanulmányaikra. Mind a három hallgató átkerült költségtérítéses képzésre, „talán ez volt az elsö dominó, ami eldölt" (Interjúalany 2). Egy ördögi kör vette kezdetét, még többet kellett dolgozniuk. A munka és a tanulmányok kombinálása pedig nem volt egyszerű, s mivel a pénzügyi kényszer erősebb volt, így a tanulás egyértelműen háttérbe szorult, s már végképp nem tudták összeegyeztetni a munkát a tanulással.

"Amikor tudtam, mentem dolgozni, igen volt rá példa, bogy ez a tanulásnak a rovására ment. Az utolsó félévekben alig volt tárgyam és igyekeztem minél többet dolgozni, és akár kevesebbet tanulni..." (Interjúalany 1 )

"Viszont ahova szinte mindennap, és éjszakában, amellett élete nem nagyon volt az embernek. Az is problémát jelentett sokszor, hogy felkelni, és bemenni órára egy éjszakai müszak után, és akkor még nem beszéltünk a tanulásra forditott idöröl, ami ekkor szinte teljesen elmaradt." (Interjúalany 2)

A harmadik interjúalany életében is folyamatosan jelen volt a munka, egyetemi évei alatt rendszeresen vállalt tipikus diákmunkákat, hogy fizetni tudja a mindennapi költségeit és a tandíját. Az ő esetében egyértelmüen érvényesült a munkaerőpiac vonzó hatása, saját döntése révén abbahagyta a nappali képzést, átiratkozott levelező tagozatra, így lehetősége nyílt, hogy még többet dolgozzon.

"Jelenleg Siófokon dolgozom egy közjegyzői irodában, de az egyetemi évek során folyamatosan dolgoztam. Most negyedéves joghallgató vagyok. Három évig nappali tagozaton végeztem az egyetemet és mellette diákmunkát vállaltam. A tavaly szeptembertöl levelezös lettem, mert teljes munkaidöben szerettem volna dolgozni, illetve eltartani magam és fizetni a tandijat. Nyáron a Balatonon voltam recepciós, de a szezon után elkezdtem itt dolgozni az irodában..." (Interjúalany 3)

A munka révén könnyebben tudja félretenni a pénzt a tandijára. Amit még pozitívumnak tart a döntésében, az az, hogy a rengeteg diákmunka után olyan munkát végez, ami kapcsolódik a tanulmányaihoz. Bár a munka, a levelező tagozat és a rengeteg utazás megnehezíti az életét, mégis úgy érzi, jól döntött.

„Fontosnak tartottam, hogy új tapasztalatokat szerezzek, a diákmunkáim teljesen más típusúak voltak... Hostesskedés, pultozás, telefonos központ, szinte minden diákszövetkezetnél dolgoztam már. A suli rengeteg idöt elvett, most én osztom be a saját idömet, beti 40 órát teljesiteni kell, néha nehéz összehozni, de nem lehetetlen." (Interjúalany 3)

$\mathrm{A} z$ első három interjúalany életében a tanulmányok ideiglenes megszakításának az oka egyértelmüen az egyetem melletti munkavégzés volt. A tanulmányaik kezdetétől végeztek valamilyen jövedelemszerző tevékenységet, amit az idő múlásával egyre nehezebben tudtak összeegyeztetni az egyetemi tanulmányaikkal. Ebből kifolyólag költségtérítéses hallgatókká váltak, így az anyagi terheik tovább nőttek, ami még intenzívebb munkavállalást eredményezett. A munkavállalás és a végbemenő változások ellenére is folytatják a tanulmányaikat: „Ha már elkezdtem, be is fejezem!” (Interjúalany 2)

A következő két interjúalanyunk a munkavállaló fiatalok azon csoportjába tartozik, akiket a szülőktől való függetlenedés vágya motivált arra, hogy munkát vállaljanak. Bár anyagilag nem voltak rászorulva a pluszjövedelemre, mégis szerettek volna dolgozni, azonban a munkavállalásuk nagymértékben veszélyeztette az egyetemi pályafutásukat. 
A z interjúalanyoknak a munkavállalás az egyetemi éveik alatt vált az életük részévé. Kezdetben nehézséget az időbeosztás okozott számukra, hogy a tanulásra, munkára, pihenésre is jusson idő.

"A hetem ezzel telik szinte, hogy dolgozok. Általában heti 5 napot, de ők alkalmazkodnak az órarendembez, tehát leadom a ráérésemet, és úgy írnak be dolgozni, hogy tudjak órára járni. Van olyan nap, hogy négy órát dolgozok, de általában kilencet. [...] Akkor elmondom a mai napom, mert abban minden volt. Reggel 8-tól volt egy órám 10-ig, utána mentem dolgozni 11-re, ott voltam 3-ig, aztán 4-töl volt egy órám, az tart 6-ig. Aztán 7-töl van edzésem 9-ig. De igazából több nap dolgozok, illetve van egy pibenö napom, amikor próbálom utolérni magam." (Interjúalany 4)

A munkavégzés mellett az interjúalanyok a választott szakirányukból fakadó problémákat nevezték meg a tanulmányi nehézségeik másik fö okaként. A problémák egyrészt a szak (jelen esetben a pedagógiai szak) negatív megítéléséből fakadtak, valamint a támogató intézményi közeg hiányából. Az említett tényezők pedig növelik a munkaerőpiac vonzó hatását, ezért is következett be, hogy az interjúalanyok a munkát választották az egyetem helyett.

„Úgy érzem, hogy ezzel a diplomával nem tudok mit kezdeni. És emiatt viszont negatív vagyok. Én itt vagyok, hogy csúszok egy évet, és itt vagyok négy évig... és tulajdonképpen a semmiért. A munkám azonban nem kapcsolódik az egyetemi tanulmányaimboz, de pozitív, hogy megtanultam csapatban dolgozni, beosztani az idömet, illetve az anyagi függetlenség. Sikerült anyagilag belyt állnom, ba már ez egyetemen nem is." (Interjúalany 4)

$\mathrm{A} z$ ötödik interjúalanyom kezdetben a szülőktől való függetlenedés miatt vállalt diákmunkát. Az első (informatika) szakról való lemorzsolódásának az oka nem a munkavállalásából fakadt, inkább intézményi oka volt. Azonban ez az ok elegendő volt ahhoz, hogy még a diákmunkákat is hasznosabbnak tartotta, mint a folyamatos bukdácsolásokat, holott a tanulás, a diploma megszerzése mindig is a céljai között szerepelt.

„A középiskolai osztályfönököm, aki a kémia és matek tanárom volt egyben, ő búzott le annyira, hogy nem volt kedvem tovább kémiát tanulni. Így informatika szakra jelentkeztem az egyetemre, fel is vettek, itt tanultam két évet. Aztán volt ez az első szünetem. Akkor volt egy passziv félévem és elmentem diákmunkára, aztán volt egy félév, amikor próbálkoztam az infóval, de nem tetszett, az a tantárgy és az a tanár... és kiléptem véglegesen. Ekkor egyéni vállalkozó lettem. Pénzügyi tanácsadó voltam, de rájöttem, hogy én nem teljesen ezt akarom csinálni, akkor jöttem vissza, de a vegyészmérnökire..." (Interjúalany 5)

A megkérdezett hallgató a negatív munkatapasztalatok miatt döbbent rá, hogy a diploma megszerzése mégiscsak előnyt jelent számára a munkaerőpiacon, így egy újabb szakra adta be a jelentkezését. Ám nem sokkal a vegyészmérnöki szak megkezdése után ismét a munkaerőpiac vonzó hatása érvényesült a hallgatónál. Jövedelemszerzés és szakmai tapasztalatszerzés miatt döntött úgy, hogy jelentkezik egy gyógyszeripari céghez dolgozni. Elmondása szerint úgy érezte, ezzel a munkával semmit nem veszíthet, inkább csak pluszismeretekre tehet szert, amire az egyetemen belül nem volt lehetősége.

"A második alkalommal, mikor passziv lettem a vegyészmérnökin belül, akkor az már tudatosabb volt, hogy akkor próbáljuk ki, hátha jobb lenne dolgozni... és akkor mentem a gyógyszeripari céghez majdnem egy teljes évre, az kapcsolódott a szakomboz. Minden munkából azért lehet valamit tanulni, úgy gondolom. Sok helyröl ezért hivnak vissza. A gyógyszeripari cégböl is sok hasznom volt, mert ismerösöket szereztem, és tudom, hogy mi kell abhoz, hogy oda 
bejussak. Megismerkedtem a fönökkel is. 60-40\%-ban arra kellett a munka, hogy pénzt szerezzek, inkább az az erösebb. Illetve egy kis rálátást kaptam, hogy kellene a jövöben haladni." (Interjúalany 5)

A z interjúalanyok között volt olyan, aki kevésbé volt előrelátó, s csak az idő múlásával ébredt rá arra, hogy a diploma a mai világban igenis számít. Középiskolás kora óta végzett már diákmunkát, leggyakrabban fizikai munkákat vállalt. Hasonlóan a többi interjúalanyhoz pozitívumnak nevezte meg, hogy a munka révén bővítette a kapcsolati hálóját és sok ismeretségre tett szert, aminek hasznát veheti. A munkavállalása azonban a tanulmányok megszakítását, majd a lemorzsolódását eredményezte. Hónapokon keresztül a tanulmányai mellett hétvégén is vállalt munkát, ami jelentősen csökkentette a tanulásra fordított idejét. Továbbá úgy vélte, hogy nincs szüksége diplomára:

„Fizetésben sem lesz nagy különbség, egy frissdiplomás vagy egy OKJ-s szakember között a jövöben." (Interjúalany 6)

A z intő jelek már az első vizsgaidőszakban jelentkeztek, ekkor döntött úgy, hogy abbahagyja az egyetemet. Egy olyan cégnél tudott elhelyezkedni, ahol a szakértelme alapján választották ki, nem pedig a megszerzett dokumentumok miatt. Fizetésben sem mutatkoztak különbségek, ez is tovább erősítette abban, hogy nem szükséges befejezni a felsőfokú tanulmányait. Az interjúalany több év munkahelyi tapasztalat után döbbent rá és győződött meg arról, hogy a munkahelyi váltáshoz és az előrejutáshoz mégiscsak szükséges legalább egy diploma megszerzése. Ezért a lemorzsolódása után pár évvel levelező tagozaton elvégezte a föiskolai képzést és ugyanazt a szakot. Ma már így fogalmaz: "Az mindennél fontosabb. Tehát az, hogy az embernek legyen egy diplomája, az a mai világban egy alap. Alapdolog."

$\mathrm{A} z$ utolsó interjúalanynál a munkaerőpiacra való vissza-visszatérés volt jellemző. Két karról, két szakról is lemorzsolódott, és a munka folyamatosan jelen volt az életében. Egy-egy munkaerőpiacon eltöltött időszak a képzés szüneteltetése után vagy egy új szak megkezdése előtt volt rá jellemző. Elmondása szerint azért választotta a munkát, mert még mindig biztosabb volt egy munkahely, mint bizonyos tárgyak teljesítése, majd az elhelyezkedése egy diplomával.

„Voltak bizonyos tárgyak, amelyeket egyszerüen lebetetlen volt teljesiteni. A ballgatók között voltak olyanok, akik 7-8 éve végezték a hároméves képzést. Az egyik tárgyból annyiszor nem sikerült a vizsgám, hogy végül két félévre szüneteltetnem kellett a képzést. Ezt követöen egy újabb szakot kezdtem el, geográfusként, azonban ezt sem fejeztem be, nem láttam a képzés munkaeröpiaci kimenetelét." (Interjúalany 7)

A harmadik szak, amit levelezőn el is végzett az andragógia képzés volt, ami abban az időszakban illeszkedett az akkori munkaköréhez. Az elvégzését nem tartotta megterhelőnek, azonban mire elvégezte, munkahelyet is váltott. Jelenlegi munkahelyén pályázatírással foglalkozik. Szabadidejében jelenleg szakmát tanul, ahol asztalos végzettséget szerez. Az egész életét, munkához való viszonyát végigkísérte a kétkezi munka pozitív megítélése, az asztalos szakmát is azért tanulja, mert elmondása szerint az irodában jelenleg „semmit” nem csinálnak, csak papírokat gyártanak.

Kvalitatív kutatásunk utolsó lépéseként összegeztük az interjúalanyok véleményét arról, hogyan lehetne csökkenteni a lemorzsolódást, milyen szerepet kellene ebben vállalniuk a felsőoktatási intézményeknek? Az interjúalanyok egy része az oktatókat, és a tanár-diák kapcsolat hiányát nevezte meg. A többség kevesellte az olyan tanárok számát, akik a gyakorlati életben, a munkaerőpiacon is tapasztaltabbak, akik a tényleges problé- 
mákkal foglalkoznak. Ugyanakkor sok esetben hiányolták, hogy nem kaptak elég segítséget problémáik megoldásában:

„Hallgatóbarát oktatókat, személyesebb kapcsolatok kialakitását szeretnénk az oktatóinkkal... ha érzelmi szálakkal kötödnek a szakboz, akkor kevesebben mennek el, de nincs idö kialakitani ezt a kapcsolatot." (Interjúalany 5)

Emellett a merev tantervi hálót és az egyetemi „szóró tárgyakat” emelték ki, amelyek nem adnak olyan ismereteket, melyek a későbbi munkavállaláshoz szükségesek lennének. A megkérdezettek egyetértettek abban, hogyha sok olyan tárgyat kell teljesíteniük, amelyeket feleslegesnek ítélnek meg, továbbá nincs minőségi oktatás, s emellett még az ösztöndíj mértéke és aránya is alacsony, akkor nem meglepő, hogy csábító a munka világa. Zárszóként az egyik interjúalany a következőt tanácsolta:

„Ha valakinél jelentkeznek a lemorzsolódásra utaló jelek, ne bagyja figyelmen kívül! Ne az legyen a hozzáállása, hogy csak egy tárgy, majd megoldom, mert az esetek nagy százalékban csak egyre nagyobb és nagyobb problémák alakulnak ki ebböl, ami akár lemorzsolódáshoz is vezethet." (Interjúalany 2 )

\section{Összegzés}

A feltáró jellegű kutatásunkból kiderült, hogy a lemorzsolódás során a munkavállalásnak lényeges szerepe van. Az interjúalanyok a lemorzsolódásuk egyik legfőbb okaként a munkavállalást jelölték meg. Néhányuknak nem volt más választása az anyagi kényszer miatt, azonban többen tudatosan választották a munkát. Úgy vélik, hogy pályakezdőként a sikeres karrier egyik feltétele a tapasztalat, azonban nem mindegy, hogy a friss diplomás valódi szakmai tapasztalattal rendelkezik-e vagy sem. Ezért az interjúalanyok a szakmai gyakorlat és a szervezettség fontosságát is hangsúlyozták. Elmondásuk szerint, kartól és szaktól függetlenül, szívesen vennének részt szakmai gyakorlaton, ahol olyan képességekre is szert tehetnek, amilyenekre az egyetem falai között nem lenne lehetőségük. Ehhez viszont nélkülözhetetlen, hogy az oktatók és hallgatók kapcsolata is átalakuljon. A hallgatók egyöntetű véleménye alapján a szakmájukhoz kapcsolódó munkák és kapcsolatok lennének a legcélravezetőbbek, amihez a felsőoktatási intézmények hozzájárulása kellene.

Néhány hallgató szerint érdemes lenne többet foglalkozni a pályázati és ösztöndíjlehetőségekkel, amelyekkel egyaránt szakmailag és anyagilag is javulna a helyzetük, így talán kevésbé lennének csábítóak a diákmunkák. Az ösztöndíjak mellett a felsőoktatási intézményeknek célszerü lenne megfontolni a munkaerőpiaccal való szoros együttmüködést, akár egy szakmai gyakorlat vagy duális képzés indításának lehetőségét. Ha a hallgatók a tanulmányaikhoz illeszkedő munkát végeznek, nemcsak anyagi biztonságban részesülnek, hanem szakmai tapasztalatban is. Továbbá szükség lenne olyan jellegú információkra, amelyek a jövőbeli munkavállalásuk során is hasznosak lehetnek, hogy legyen tiszta és világos képük arról, hogy a szakmájukkal hol és hogyan tudnak elhelyezkedni.

Jelenleg nem lehet egyszerüen megítélni, hogy az egyetem melletti munkavállalás milyen erős rizikófaktor, hiszen többen tudatosan választották az egyetem helyett a munkát. Ez a döntés pedig felvet egy újabb kérdést: Hogyan tudná a felsőoktatási intézmény a javára fordítani ezeknek a hallgatóknak az észrevételeit és tapasztalatait? 


\section{IRODALOM}

Beerkens, M., Mägi, E. \& Lill, L. (2011) University Studies as a Side Job. Causes and Consequences of Massive Student Employment in Estonia. Higher Education, Vol. 61. No. 6. pp. 679-692.

Bocsi V. (2013) Munkaértékek a felsőoktatásban. In: Darvai T. (ed.) Felsőoktatás és munkaeröpiac - eszményektöl a kompetenciák felé. Szeged, SETUP-Belvedere Meridionale. pp. 67-87.

Bocsi, V., Fényes, H. \& Markos, V. (2017) Motives of Volunteering and Values of Work Among Higher Education Students. Citizenship Social and Economics Education, Vol. 16. No. 2. pp. 117-131.

Darmody, M. \& Smyth, E. (2008) Full-time Students? Term-time Employment among Higher Education Students in Ireland. Journal of Education and Work, Vol. 21. No. 4. pp. 349-362.

Derényi A. (2015) Bizonyítékokra alapozott kormányzás és a kommunikáció képzés. Ujj jel-kép, Vol. 4. Klnsz. 1. pp. 21-34.

Fenyves V., Bácsné Baba É., Szabóné Szőke R., Kocsis I., Juhász Cs., Maté E. \& Pusztai G. (2017) Kísérlet a lemorzsolódás mértékének és okainak megragadására a Debreceni Egyetem Gazdaságtudományi Kar példáján. Neveléstudomány, Vol. 5. No. 3. pp. 5-14.

Kocsis Zs. (2017) A hallgatói munkavállalás jellemzői a debreceni és a nyíregyházi egyetemisták körében. PedActa, Vol. 7. No. 1. pp. 81-89.

Kun A. I. (2013) Oktatási jelzés és szürés a munkaerőpiacon - az empirikus vizsgálatok tanulságai. Competitio, Vol. 12. No. 2.pp. 39-60.

LuкÁcs F. \& Seвő T. (2015) Az egyetemi lemorzsolódás kérdőíves vizsgálata. Iskolakultúra, Vol. 25. No. 10. pp. 78-86.

Markos V. (2014) Egyetemisták a munka világában. In: Fényes H. \& Szabó I. (eds) Campus-lét a Debreceni Egyetemen. Ifjúságszociológiai tanulmányok. Debrecen, Debreceni Egyetemi Kiadó.

Masevičiūté, K., Šaukeckiené, V. \& Ozolinčiūté, E. (2018) Combining Studies and Paid Jobs. Thematic review. UAB "Araneum", Vilnius (Lithuania). 7-67. ISBN 978-609468-169-1. https://www.eurostudent.eu/download_files/documents/TR_paid_jobs.pdf [Letöltve: 2019. 10. 09.]

McCoy, S. \& Sмyтr, E. (2004) At Work in School. Dublin, ESRI/Liffey Press.

OECD (2012) Equity and Quality in Education: Supporting Disadvantaged Students and Schools. Paris, OECD Publishing, http://dx.doi.org/10.1787/9789264130852

Perna, L. (2012) Understanding the Working College Student New Research and Its Implications for Policy and Practice. Sterling, Stylus Publishers.

Pusztai G. (2011) A láthatatlan kéztöl a baráti kezekig. A ballgatói értelmező közösségek a felsőoktatásban. Budapest, Új Mandátum.

Riggert, S. C., Boyle, M., Petrosko, M. J., Ash, D. \& Rude-Parkins, C. (2006) Student Employment and Higher Education: Empiricism and Contradiction. Review of Educational Research, Vol. 76. No. 1. pp. 63-92.

Roshchin, S. \& Rudakov, V. (2015) Russian University Student and the Combination of Study and Work: Is It All about Earning, Learning or Job Market Signaling? Working Papers Series: Education WP BRO 24/EDU/2015. National Research University Higher School of Economics. https://memo.hse.ru/data/2015/03/18/1092801357/ Roshchin,\%20Rudakov_Russian\%20university\%20students.pdf [Letöltve: 2019. 10. 09.] 
Sanchez-Gelabert, A., Figueroa, M. \& Elias, M. (2017) Working Whilst Studying in Higher Education. The Impact of the Economic Crisis on Academic and Labour Market Success. European Journal of Education, Vol. 52. No. 2. pp. 232-245.

A cikk a Creative Commons Attribution 4.0 International License (https://creativecommons.org/licenses/ by/4.0/) feltételei szerint publikált Open Access közlemény, melynek szellemében a cikk bármilyen médiumban szabadon felhasználható, megosztható és újraközölhető, feltéve, hogy az eredeti szerző és a közlés helye, illetve a CC License linkje és az esetlegesen végrehajtott módosítások feltüntetésre kerülnek. (SID_1) 